\title{
Kronik obstrüktif akciğer hastalığı ve periodontal hastalık ilişkisi
}

\author{
Association between chronic obstructive pulmonary disease and periodontal disease
}

\author{
Abdulsamet Tanik ${ }^{1}$, Fatih Demirci' ${ }^{2}$, M. Sinan Doğan ${ }^{3}$, Arzum Güler Doğrư ${ }^{1}$
}

\section{ÖZET}

Kronik obstrüktif akciğer hastalığı (KOAH) morbiditesi ve mortalitesi yüksek ve artmakta olan bir hastalıktır. Sigara tüketimine bağlı olarak KOAH tüm dünyada özellikle gelişmekte olan ülkelerde giderek artan bir salgın hastalık haline gelmektedir. Kırk yaşın üstünde, topluma katkıda bulunan erişkin nüfusu etkilemektedir. $\mathrm{KOAH}$ zararlı gaz ve partiküllere, özellikle sigara dumanına karşı oluşmuş akciğerlerde hava yollarını, interstisyum ve damar yatağını etkileyen anormal inflamatuvar cevapla karakterize sistemik bir hastalıktır. Birçok çalışmada, KOAH gibi sistemik durumlar periodontitis için bir risk faktörü olduğu saptanmıştır. Bakterilerle yapılan birçok çalışmada, akciğer enfeksiyonu yapan mikroorganizmalar ile oral kavitede yaşayan mikroorganizmanın aynı olduğu ispatlanmıştır. Bu nedenle bu konu ile ilgili, daha uzun süreli, geniş popülasyonlar üzerinde yapılan, klinik mikrobiyolojik ve epidemiyolojik çalışmalara intiyaç vardır.

Anahtar kelimeler: Kronik obstrüktif akciğer hastalığı, respiratuvar enfeksiyonlar, periodontitis.

\section{GíRíș}

Kronik obstrüktif akciğer hastalığ $(\mathrm{KOAH})$ zararlı gaz ve partiküllere, özellikle sigara dumanına karşı oluşmuş akciğerlerde hava yollarını, interstisyum ve damar yatağını etkileyen anormal inflamatuvar cevapla karakterize sistemik bir hastalıktır. Akciğer tutulumu ilerleyici hava yolu obstrüksiyonu ile karakterizedir. Önlenebilir ve tedavi edilebilir bir hastalıktır [1]. KOAH inflamatuvar bir hastalıktır, bu inflamasyonda çok sayıda hücre (epitel-endotel hücreleri, makrofajlar, nötrofiller, CD8+ T-lenfositleri, hatta eosinofiller, CD4+ T-lenfositleri ve mast hücreleri), hücre ürünleri (TNF- $\alpha$, IL-8, IL-6,

\begin{abstract}
Chronic Obstructive Pulmonary Disease (COPD) morbidity and mortality is high and increasing levels of a disease. COPD is becoming a growing epidemic due to smoking consumption especially in developing countries all over the world. Above the age of forty, affects adult population contributing to the community. COPD is characterized by a progressive, irreversible limitation of airflow associated with an abnormal inflammatory response to noxious particles or gases. It is caused primarily by smoking. In many studies, systemic conditions such as COPD were found to be a risk factor for periodontitis. In many studies with bacteria, has proven to be the same microorganisms in the oral cavity with microorganisms which lung infection. Therefore, on this subject, longer, with the large populations, clinical, microbiological and epidemiological studies are needed.
\end{abstract}

Key words: Chronic obstructive pulmonary disease, respiratory infections, periodontitis

TGF- $\beta$, IFN- $\gamma$, fibrinojen ve CRP, vb.) rol oynamaktadir $[2,3]$.

KOAH' da ekspiratuar akım kisitlanmasinı temelde etkileyen faktörler periferik küçük hava yollarındaki kronik obstrüktif bronşiyolit ve parankimdeki destrüksiyon (alveol duvarında hava yolu açıklığını sağlayan tutamakların kaybı, amfizem) komponentleridir.

\section{EPIDEMIYYOLOJI}

KOAH tüm dünyada giderek artan önemli bir morbidite ve mortalite nedenidir. Dünya Sağlık Örgütü

${ }^{1}$ Dicle Üniversitesi Diş Hekimliği Fakültesi Periodontoloji Anabilim Dall, Diyarbakır, Türkiye

${ }^{2}$ Dicle Üniversitesi Diş Hekimliği Fakültesi Protetik Diş Tedavisi Anabilim Dall, Diyarbakır, Türkiye

${ }^{3}$ Dicle Üniversitesi Diş Hekimliği Fakültesi Çocuk Diş Hekimliği Anabilim Dall, Diyarbakır, Türkiye

Yazışma Adresi /Correspondence: Abdulsamet Tanik,

Dicle Üniversitesi Diş Hekimliği Fakültesi, Periodontoloji Anabilim Dalı, Diyarbakır, Türkiye Email: samet.120a@ gmail.com

Geliş Tarihi / Received: 04.01.2015, Kabul Tarihi / Accepted: 16.02.2015

Copyright @ Dicle Tıp Dergisi 2015, Her hakkı saklıdır / All rights reserved 
(DSÖ) verilerine göre 1998'de dünyada 600 milyon KOAH' lı hasta bulunmaktadır ve her yıl KOAH nedeniyle 2.3 milyon kişi ölmektedir. Günümüzde ise her y1l KOAH' tan 2.74 milyon kişi ölmektedir [3]. KOAH, 1990'da tüm dünyada en s1k görülen 6.ölüm nedeni iken, 2020 'de 3. Ölüm nedeni olmas1 beklenmektedir. Sigara tüketimine bağlı olarak $\mathrm{KOAH}$ tüm dünyada özellikle gelişmekte olan ül- kelerde giderek artan bir salgın hastalık haline gelmektedir [4].

KOAH genellikle sosyoekonomik durumu düşük toplumların hastalığıdır. Ek olarak semptomlar ile hava akımı obstrüksiyonunun şiddeti arasındaki ilişki zayıftır. Bu nedenle hastalığın prevalansını saptamak zordur.
Tablo 1. Kronik obstrüktif akciğer hastalığında risk faktörleri

\begin{tabular}{ll}
\hline Çevresel faktörler & Konakçı ile ilgili faktörler \\
\cline { 1 - 2 } Sigara içimi & \\
Aktif sigara içimi & \\
Pasif sigara içimi & \\
Annenin sigara içimi & Alfa-1 antitripsin eksikliği \\
Mesleki karşılaşmalar & Genetik faktörler \\
Hava kirliliği & Aile öyküsü \\
Dış ortam & Etnik faktörler \\
İç ortam & Yaş \\
Sosyoekonomik faktörler/yoksulluk & Hava yolu aşırı yanıtıığı \\
Diyetle ilgili faktörler & Atopi \\
Yüksek tuzlu diyet & Düşük doğum ağırlığı \\
Diyette antioksidan vitaminlerin azlığı & Semptomlar (aşırı mukus yapımı vb) \\
Diyette doymamış yağ asitlerinin azlığı & \\
Enfeksiyonlar & \\
\hline
\end{tabular}

\section{RİSK FAKTÖRLERİ}

$\mathrm{KOAH}$ gelişiminde önemli risk faktörleri sigara kullanımı, mesleki maruziyet ve alfa-1 antitripsin (AAT) eksikliğidir. Tablo 1'de KOAH' taki risk faktörleri görülmektedir.

Tütün ürünlerinin özellikle en s1k kullanılan sigaranın KOAH oluşmasındaki rolü \%80-90'dır. Sigara kullananların yaklaşık yarısında öksürük ve balgam çıkarma ile karakterize kronik bronşit olurken, genetik duyarlılık ve olumsuz çevre faktörlerinin karş1lıklı etkileşimi sonucu \%15-20'sinde KOAH gelişmektedir. Annenin sigara içimi ve pasif sigara içimi de önemli bir risk faktörü oluşturmaktadir [5].

Meslek nedeniyle toz, duman ve gazlar gibi irritanlara maruz kalmak KOAH oluşmasında etkilidir. Silika, kömür ve kadmiyum gibi maden ve metal işçiliği, ulaşım sektörü, odun /kağıt üretimi, çimento üretimi, tahıl, pamuk ve yün işçiliği en önemli risk gruplarındandır.

İç ve diş ortam hava kirliliğinin rolü sigaraya göre oldukça azdır. Kentlerdeki hava kirliliğinin akciğer ve kalp hastalıklarını olumsuz yönde etki- lediği gösterilmiştir. Evlerde 1sınma ve yemek pişirme amacıyla kullanılan odun, kömür gibi bitkisel ve tezek gibi hayvansal yakıtlar karbonmonoksit ve nitrik oksitin açı̆̆a çıkmasına neden olur. Havalanmanın yetersiz olduğu durumlarda ev içi ortam kirliliğine yol açarak KOAH gelişiminde rol oynayabilirler. $\mathrm{Bu}$ yakıtlardan ev içine yayılan karbonmonoksit, kükürt dioksit, azot oksit ve dioksit başta olmak üzere birçok gazın veya partiküllerin akciğerlerde önemli hasar yaptığı bilinmektedir. Yaşamın ilk yılında geçirilen akciğer infeksiyonları özellikle adenovirus enfeksiyonları, ilerleyen yıllarda KOAH' a yol açabilir [6,7]. Özellikle çocukluk çağında astım geçiren hastaların 40 yaşından sonra KOAH oluşma oranının yüksek olduğu belirtilmiştir [8]. Bu nedenlerden dolayı KOAH oluşumunu önleme programlarının çocukluk çağında teşhis edilen solunum sistemi hastalıklarının önemini ortaya çıkarmaktadır [9]. Fakat daha sonraki yıllarda geçirilen akciğer enfeksiyonlarının bu yöndeki rolü net olarak bilinmemektedir [6,7]. Ayrıca D vitamini eksikliği ile KOAH oluşumu arasında ilişki olduğu belirtilmiștir [10]. 
Alfa-1 antitiripsin (AAT), KOAH' a neden olduğu bilinen tek genetik anormalliktir. AAT, proteolitik enzimlerin majör inhibitörü olup, alt solunum yollarında kuvvetli bir doku yıkıcı proteaz olan nötrofil elastazın akciğer dokusunda yaratacağı yıkımı önler. Bazı ailelerde AAT eksikliği bulunmaksızın amfizemin daha sık görüldüğü gözlenmektedir. Genetik faktörlerin önümüzdeki yıllarda daha net anlaşılacağ1 kesindir. KOAH' 11 hastaların çoğunda havayolu hiperaktivitesi vardır. Kronik havayolu obstrüksiyonunun temelinde "Astmatik bünye" (atopi, IgE ve eozinofil yüksekliği) bulunduğunu, bununla birlikte sigara içiminin etkisiyle de kronik havayolu obstrüksiyonunun ortaya çıktığı ileri sürülmektedir. Bir risk faktörü olarak cinsiyetin KOAH gelişimindeki rolü iyi bilinmemektedir [11]

Geçmişte yapılan çalışmaların çoğunda $\mathrm{KOAH}$ prevalansı ve mortalitesinin kadınlara göre erkeklerde daha yüksek olduğu saptanmıştır. Son yıllarda gelişmiş ülkelerde yapılan çalışmalar hastalık prevalansının kadın ve erkeklerde birbirine yakın olduğunu göstermektedir. Bu durum muhtemelen sigara içme davranışlarındaki değişikliği yansıtmaktadır. Bununla birlikte bazı çalışmalarda kadınların erkeklerden daha fazla sigara dumanından etkilendikleri ileri sürülmektedir. Bu durum, kadınlar arasında sigara içenlerin oranının hem gelişmiş, hem de gelişmekte olan ülkelerde giderek artması nedeniyle önemli bir sorun oluşturmaktadır [12].

\section{Doğal Seyir}

KOAH' l1 hastalarda FEV1 hastadan hastaya değişmekle birlikte, genellikle y1lda $50 \mathrm{ml}$ ' den çok azalır. Normalde ise bu azalma 18-30 ml kadardır. Fletcher ve Peto'nun çalışmaları [13], sigara içenlerin yalnız \%10-20'sinin sigaraya duyarlı olduğunu ortaya koymuştur. İçilen sigara miktarı arttıkça mortalite artmaktadır. Sigarayı birakanlarda ise akciğer fonksiyonlarındaki azalma normal hızına düşmektedir. Bu sonuçlar, ABD'de yapılan akciğer sağlığı çalışması ile doğrulanmıştır.

\section{SEMPTOM VE BULGULAR}

KOAH' nın en belirgin semptomları olan öksürük ve balgam çıkarma, hastalığın başlangıcından beri mevcuttur. Ancak şiddeti hafif olduğundan başlangıçta hasta tarafından önemsenmez ve sigara içi- mine bağlanır. Balgam çıkarma başlangıçta sadece sabahları söz konusu iken, zamanla günün diğer saatlerinde de görülmeye başlar [14].

Hastalarda başlangıçta ağır eforlarda, daha sonraları günlük yaşantısında ortaya çıkan nefes darlığı vardır. KOAH' da hış1ltılı (wheezing) solunum görülür. Hış1ltılı solunum ve dispne yanlışlıkla astma olarak değerlendirilebilir. Hastalık ilerledikçe yıllık atak sayısı artar. İleri aşamalarda hipokseminin sonucu olarak siyanoz gelişir. Bronşitin egemen oldu$\breve{g u}$ olgularda hipoksemi ile birlikte hiperkapni de oluşur. Sabahları ortaya çıkan baş ağrısı hiperkapniyi düşündürmelidir. Hipoksemik ve hiperkapnik hastalarda sağ kalp yetmezliği ve ödem gelişmektedir [15].

KOAH'in stabil ve akut alevlenme dönemlerinde C-reaktif protein (CRP), beyaz küre (BK), interlökin-6 gibi sistemik inflamasyonu gösteren çeşitli belirteçlerin artmış olduğu gösterilmiştir [16].

\section{KOAH VE PERİODANTAL DURUM İLISSKİSI}

Periodonsiyum ile ilgili olarak meydana gelen çeşitlikli bozukluklar içinde en çok karşılaşılan gingivitis ile periodontitis olup, bu hastal1klar kronik enfeksiyöz hastalıklardır. Periodontal hastalıkların nedenleri arasında konağa ait faktörler ile bakteriyel ve çevresel faktörlerin karş1lıklı etkileşimleri sayılabilir. Sistemik hastalık, yaş, immün sistemin durumu, oklüzal travma ve stres gibi konağa bağ ${ }_{1}$ faktörler periodontal hastalığın seyrini etkileyebilir.

Mikrobiyal dental plak ile diş protezlerinde biriken plağın kompozisyonu farklıdır. Diş protezlerdeki plak ve kötü protez hijyeni de potansiyel enfeksiyöz patojenler için bir rezervuar olarak hizmet edebilir. Protezlerde biriken plaktaki mikroorganizmalar; diş çürügü, periodontitis, bakteriyel endokardit, aspirasyon pnömonisi, gastrointestinal enfeksiyonları ve KOAH için bir depo vazifesini görmektedir. Etkili bir ağız hijyeni uygulaması ile protezlerdeki plak biyofilmi kontrol etmek önemli$\operatorname{dir}[17]$.

KOAH, popülasyonun büyük bir kısmını etkileyen respiratuvar bir hastalıktır. Son yapılan çalışmalarda respiratuar hastalıklarla periodontal hastalıklar arasındaki ilişkiyi destekleyen bulgulara ulaş1lmıştır [18]. Diş ve periodonsuyum, respiratuvar enfeksiyonlar için bir rezervuar olarak düşünülmek- 
tedir. Dental plağın, pnömoni ve diğer respiratuvar enfeksiyonların etiyolojisinde rol oynayan anaerobik patojenler için önemli bir lokal kaynak olduğu düşünülmektedir. Büyük oranda geri dönüşümsüz ve hava yolu kısitlaması ile karakterize ilerleyici tarzda bir hastalık olan KOAH'1n kronik bronșit ve amfizem olarak adlandırılan iki önemli komponenti bulunmaktadır [19] .

Respiratuvar enfeksiyonların patogenezinde oral bakterilerin etkisi ile ilgili olası mekanizmalar şöyle sıralanmaktadır.

\section{Oral patojenlerin akciğere aspirasyonu}

Salyada bulunan periodontal hastalıkla ilişkili enzimlerin, mukozal yüzeyleri modifiye ederek respiratuvar patojenlerin adezyon kolonizasyonunu artırmas1.

Periodontal hastalıkla ilişkili salyadaki enzimlerin salivar pellikıllı yıkarak, respiratuvar patojenlere karşı spesifik olmayan konak defansın koruyuculuğunu azaltması .

Periodontal dokulardan kaynaklanan sitokinlerin ( IL-1a ,IL-1b , IL-6 , IL-8 , ve TNF-a ) respiratuvar epiteli değiştirerek, respiratuvar patojenlerin kolonizasyonuna yatkın hale getirmesi [20] .

Oral kavite akciğerlerle olan anatomik devaml1lığı nedeniyle solunum yolu patojenleri için potansiyel bir rezervuardır [21,22]. Yapılan birçok mikrobiyolojik çalışmada akçiğer enfeksiyonu yapan mikroorganizmalar ile oral kavitede yaşayan mikroorganizmaların aynı olduğu saptanmıştır $[23,24]$. Oral kavitede, patojen bakterilerin kolonize olmas1nin sonucunda oro-farangeal enfeksiyonlara neden olabileceği ve takiben respiratuar hastalıkların gelişiminde etkili olabileceği saptanmıştır [4]. Ağzında kendi dişleri olan bireylerde dişsiz bireylere göre pnömoni ve hava yolu enfeksiyonları gelişme riski daha yüksektir. Bakım evlerinde kalan hastalarda salya ve dental plaktaki karyojenik ve periodontal potojenlerin aspirasyon pnömonisinde risk oluşturduğu rapor edilmiştir $[18,20]$. Yoğun bakımda yatan hastalarda uygulanan antiseptik gargara veya oral antibiyotik kombinasyonlarının pnömoni oluşumunu azalttığını rapor eden çalışmalar, bu ilişkiyi desteklemektedir $[23,25]$.

Respiratuar hastalıklar ve ağız sağlığı arasındaki potansiyel ilişkiye ilk olarak Scannepieco ve arkadaşlarının çalışmasında değinilmiştir [18]. Yapılan çalışmada kronik respiratuar hastalığı olan bireylerde daha yüksek oral hijyen skorları ve daha çok sayıda çürük tespit edilmiştir[26]. Respiratuar hastalığ durumları hem de kullandıkları ilaçların etkisiyle çürük oluşum oranı yüksek olduğu bildirilmiştir [27]. Ayrıca KOAH' 11 hastalarda periodontal ataşman kaybının daha fazla olduğu saptanmıştır [26]. $\mathrm{Bu}$ sonuçlar Hayes ve arkadaşlarının çalışmasında da desteklenmiştir. Periapikal radyografilerle belirlenen alveolar kemik kaybı, yetişkin erkeklerde $\mathrm{KOAH}$ için risk faktörü olarak belirlenmiştir [22,28-29].

KOAH ve periodontal durum arasındaki ilişkiyi araştıran çalışmalar, kötü oral hijyenin ve periodontal durumun $\mathrm{KOAH}$ oluşumunda önemli bir role sahip olduğunu göstermiştir $[4,21,26]$. Yine bu çalışmalarda respiratuar hastalıkların ve tekrarlayan ataklarının önlenmesinde, oral kavitenin bir rezervuar gibi çalışmasının önlenmesi, yani kötü oral hijyenin düzeltilmesi ve patojen mikrofloranın azaltılmasının önemi üzerinde durulmaktadır [22,30]. KOAH' l1 hastalarda dental işlemler sırasında solunum güçleşebileceğinden dik oturtulması tavsiye edilmektedir [31].

\section{SONUÇ}

KOAH ve periodontal durum arasındaki ilişkiyi araştıran çalışmalar daha geniş popülasyonlarda ve uzun süreli olarak yapılmalıdır. İki hastalık arasındaki patolojik mekanizma tam olarak açıklığa kavuşturulursa, hem respiratuar hastalıklardan kaynaklanan periodontitisin önlenmesinde ve tedavisinde, hem de kötü ağız hijyeninin tetiklediği respiratuar hastalıkların önlenmesinde hem de $\mathrm{KOAH}$ ataklarının azaltılmasında olumlu sonuçlar doğuracaktır. Bu nedenle bu konu ile ilgili, daha uzun süreli, geniş popülasyonlar üzerinde yapılan, klinik mikrobiyolojik ve epidemiyolojik çalışmalara ihtiyaç vardır.

\section{KAYNAKLAR}

1. Global Strategy for the Diagnosis, Management, and Prevention of COPD. Available at: www.goldcopd.com. Accessed Apr 2015. 
2. Barnes PJ (ed). Chronic Obstructive Pulmonary Disease; Cellular and Molecular Mechanisms. Boca Raton, Taylor\&Francis Group, 2005;253-278.

3. MacNee W, ZuWallack RL, Kenann J (eds). Clinical Management of Chronic Obstructive Pulmonary Disease. West Islip, Professional Comm, Inc., 2005;367-384.

4. Scannapieco FA, HoAW. Association of periodontal disease and chronic lung disease Analysis of NHANES III. J Dent Res 1999;78:1777-1782.

5. Kurtulgan O, Mete A, Uyar M. Kronik obstrüktif akciğer hastalığında ekspiratuar yüksek rezolüsyonlu bilgisayarlı tomografi bulguları ile trakeal indeks ve solunum fonksiyon testleri arasındaki ilişki. Dicle Med J. 2012;39:42-48.

6. Barnes PJ, Celli BR. Systemic manifestations and comorbidities of COPD. Eur Respir J 2009;33:1165-1185.

7. Yıldırım N. KOAH patogenezi. Ed: S. Umut, N. Yıldırım Kronik Obstrüktif Akciğer Hastalığı (KOAH). Ed. İstanbul: Turgut yayınc1lık; 2005:41-58.

8. Mattes, Joerg, and Peter G. Gibson. The early origins of COPD in severe asthma: the one thing that leads to another or the two things that come together?. Thorax 2014;69:789 790.

9. Rubin Bruce K. Respiratory care year in review 2010: part 1. asthma, COPD, pulmonary function testing, ventilatorassociated pneumonia. Respiratory care. 2011;56: 488-502.

10. Herr C. The role of vitamin D in pulmonary disease: COPD, asthma, infection, and cancer. Respir Res 2011; 12: 31.

11. Pride N. Smoking, allergy and airways obstruction: revival of the "Duck hypothesis". Clin Allergy 1986;16:3-6.

12. Szafranski W, Cukier A, Ramirez A. et al. Efficacy and safety of budesonide/formoterol in the management of chronic obstructive pulmonary disease. Eur Respir J 2003;21:74-81.

13. Fletcher C, Peto R. The natural history of chronic airflow obstruction. Br Med J 1977;1:1645-1648.

14. Erdinç E, KOAH atağ1. In: Ekim N, Türktaş H. Göğüs Hastalıkları Acilleri. 1st ed. Ankara, Bilimsel Tıp Yayınevi 2000;231-239.

15. Bourbeau J, Nault D, Boryck1 E (eds). Comprehensive Management of Chronic Obstructive Pulmonary Disease. London: BC Decker Inc., 2002:73-84.

16. Erden E. Ş, Dokuyucu R, Demirköse M. et al. Kronik obstrüktif akciğer hastalığının akut alevlenme ve stabil dönemlerinde ortalama trombosit hacminin incelenmesi. J Clin Exp Invest 2013;4:483-487.

17. Coulthwaite L, Verran J. Potential pathogenic aspects of denture plaque. British J Biomed Sci 2007;64:180-189.
18. Scannapieco FA. Genco RJ. Association of periodontal infections with atherosclerotic and pulmonary disaeses. J Periodontal Res 1999;34:340-345.

19. Pauwels RA, Lofdahl CG, Laitinen LA. et al. Long-term treatment with inhaled budesonide in persons with mild chronic obstructive pulmonary disease who continue smoking: European Respiratory Society Study on Chronic Obstructive Pulmoary Disease. N Engl J Med 1999;19481953.

20. Scannapieco FA. Role of oral bacteria in respiratory infection. J Periodontal.1999;70:793-802.

21. Scannapieco FA. Potential association between chronic respitory disease : Analysis of National Health and Nutrition Examination Survey III. J Periodontal 2001;72:50-56.

22. Scannapieco FA, Papandonatos GD, Dunford RG. Associations between oral conditions and respiratory disease in a national sample survey population. Ann Periodontal 1999;3:251-256.

23. Finegold SM. Aspiration pnuemonia. Rev Infect Dis 1991;13:737-742.

24. Morris JF, Sewell DL. Necrotizing pnuemonia caused by mixed infection with Actinobacillus actinomycetemcomitans and Actinomyces israeli: Case report and review. Clin Infect Dis 1994; 18.450-452.

25. Scannapieco FA, Bush RB, Paju S. Associations between periodontal disease and risk for nasocomial bacterial pnuemonia and chronic obtrüctive pulmonary disease. A sytemic review. Ann Periodontal 2003;8:54-69.

26. Murphy TF, Sethi S. Bacterial infection in chronic obstructive pulmonary disease. Am Rev Respir Dis.1992;146:10671018.

27. Widmer, Richard P. Oral health of children with respiratory diseases. Paediatric Resp Rev 2010;11:226-232.

28. Teng YT, Taylor GW, Scannapieco F. et al. Periodontal health and systemic disorder. J Can Dent Assoc 2002;68:188-192.

29. Wilson M, Reddi K, Henderson B. Cytokine-inducing components of periodontopathogenic bacteria. J Periodontal Res 1996;31:393-407.

30. Scannapieco FA, Wang B, Shiau HJ. Oral bacteria and respiratory infections : Effects on respiratory pathogen adhesion and epitheial cell proinlammantory cytokine production. Ann Periodontal 2001;6:78-86.

31. Tuncer, B. Medikal sorunlu bireylerde ortodontik yaklaşımlar. Atatürk Üniv Diş Hek Fak Derg 2005;15:40-51. 